\title{
A FOSSIL ALBATROSS FROM THE EARLY OLIGOCENE OF THE NORTH SEA BASIN
}

\author{
Gerald MAYr ${ }^{1,3}$ AND ThIERry SMITH ${ }^{2}$ \\ ${ }^{1}$ Forschungsinstitut Senckenberg, Sektion Ornithologie, Senckenberganlage 25, D-60325 Frankfurt am Main, Germany; and \\ ${ }^{2}$ Royal Be lgian Institute of Natural Sciences, Department of Paleontology, Rue Vautier 29, B-1000 Brussels, Belgium
}

\begin{abstract}
We describe a stem group representative of Diomedeidae from the early Oligocene (Rupelian) of Belgium. The fossil remains, wing, and pectoral girdle bones of two individuals are described as Tydea septentrionalis, gen. et sp. nov., and constitute the earliest well-established record of the taxon and the first Paleogene record from the North Sea Basin. The new species was about the size of the extant Black-browed Albatross (Thalassarche melanophris) and establishes that albatrosses had already reached a large size 30 mya. The wing bones of T. septentrionalis are distinguished by several plesiomorphic features from those of species in crown group Diomedeidae, which may indicate differences in aerodynamic performance between the fossil species and extant albatrosses. We detail that a previously described early Miocene species, "Plotornis" arvernensis, should be expunged from the fossil record of albatrosses. However, the new fossils provide further evidence that the extant, mainly Southern Hemispheric, distribution of albatrosses is relictual compared with the past distribution of the total group (stem group + crown group). With unambiguous records from the early Oligocene, early Miocene, and Pliocene, albatrosses are now known to have had a long evolutionary history in the European part of the North Atlantic, but the reasons for their extinction remain poorly understood. Received 7 September 2011, accepted 29 September 2011.
\end{abstract}

Key words: Diomedeidae, evolution, fossil birds, gen. et sp. nov., Rupelian, Tydea septentrionalis.

\section{Un Albatros Fósil del Oligoceno Temprano en la Cuenca del Mar del Norte}

Resumen.-Describimos un grupo basal ("stem group") representante de Diomedeidae del Oligoceno temprano (Rupeliano) de Bélgica. Los restos fósiles, ala y huesos de la cintura pectoral de dos individuos son descritos como Tydea septentrionalis, gen. et. sp. nov., y constituyen el registro más antiguo y bien establecido del taxón y el primer registro del Paleógeno de la cuenca del Mar del Norte. La nueva especie tenía el tamaño aproximado de la especie viviente Thalassarche melanophris, por lo cual se establece que los albatros ya habían alcanzado un gran tamaño hace 30 millones de años. Los huesos del ala de T. septentrionalis se distinguen en varias características plesiomórficas de aquellos presentes en especies del clado formado por los Diomedeidae vivientes, lo que puede indicar diferencias en el desempeño aerodinámico entre la especie fósil y los albatros vivientes. Presentamos detalles que indican que una especie del Mioceno temprano anteriormente descrita, "Plotornis" arvernensis, debería ser eliminada del registro fósil de los albatros. Sin embargo, los fósiles proveen evidencia adicional de que la distribución actual de los albatros, principalmente del hemisferio Sur, es relictual comparada con la distribución pasada del todo el grupo entero (grupo basal + clado de especies vivientes). Con base en registros no ambiguos del Oligoceno temprano, el Mioceno temprano y el Plioceno, ahora se conoce que los albatros han tenido una historia evolutiva larga en la parte europea del Atlántico norte, pero las razones de su extinción continúan siendo poco entendidas.

The Extant Diomedeidae (albatrosses and mollymawks) are classified in four genera, Diomedea, Thalassarche, Phoebetria, and Phoebastria, which, depending on the author, include 14 to 24 species (Nunn et al. 1996, Brooke 2004). Most diomedeids occur in the Southern Hemisphere, with only three species of the genus Phoebastria breeding in the northern part of the Pacific Ocean (Carboneras 1992). Probably as a result of their highly pelagic way of living and despite their large size and wide distribution, albatrosses have a comparatively scant fossil record. Most of the known fossil species were recovered from Miocene or Pliocene deposits of North America (Olson 1985b, Olson and Rasmussen 2001, Warheit 2002), and the early history of the group is very poorly known.

In the Neogene of the Southern Hemisphere, Diomedeidae were reported from the late Miocene of Australia ("Diomedea" thyridata; Wilkinson 1969), the early Pliocene of Africa (Olson 1985a), the early Miocene of Argentina (Olson 1984), and the late Miocene-early Pliocene of the Bahía Inglesa and Pisco Formations in Chile and Peru (Walsh and Hume 2001, Stucchi and Urbina 2005).

${ }^{3}$ E-mail: gerald.mayr@senckenberg.de

The Auk, Vol. 129, Number 1, pages 87-95. ISSN 0004-8038, electronic ISSN 1938-4254. ( 2012 by The American Ornithologists' Union. All rights reserved. Please direct all requests for permission to photocopy or reproduce article content through the University of California Press's Rights and Permissions website, http://www.ucpressjournals. com/reprintInfo.asp. DOI: 10.1525/auk.2011.11192 
"Diomedea" californica Miller, 1962 and "D." milleri Howard, 1966 were described from the middle Miocene of the North American Pacific coast (Olson 1985b, Warheit 2002). The former of these two species was likened to Phoebastria anglica (see below) by Olson and Rasmussen (2001), who also referred Diomedea howardae Chandler, 1990 from the late Pliocene of California as well as albatross remains from the Miocene of Florida to the extant Phoebastria albatrus. Another North Pacific albatross, Diomedea tanakai Davis, 2003 from the early Miocene of Japan, was considered to be the earliest fossil representative of the genus Diomedea (Davis 2003).

Diomedeidae were also reported from the Atlantic coast of North America, where albatrosses today occur only as vagrants. A still undescribed distal humerus from the middle Miocene Calvert Formation of Maryland was mentioned by Olson (1985b), and abundant material of two extinct and three extant diomedeid species, all in the genus Phoebastria, was found in the early Pliocene Yorktown Formation of the Lee Creek Mine in North Carolina (Olson and Rasmussen 2001). The latest record of Diomedeidae in the North Atlantic dates from the Pleistocene of the Bermudas, where Phoebastria albatrus had a breeding colony until 400,000 years ago (Olson and Hearty 2003).

Several fossil albatrosses have also been reported from the Cenozoic of Europe, but identification of some of these has not been convincingly established. One of the uncontroversial records is Plotornis delfortrii Milne-Edwards, 1874 from the early Miocene of the Atlantic coast in southwestern France (Fig. 1C, E), which is represented by a tarsometatarsus and distal humeri (Milne-Edwards 1874). Cheneval's (1984) classification of another species, "Plotornis" arvernensis from the early Miocene of central France, into Diomedeidae, however, seems to be unjustified, and the material needs to be restudied in order to determine its affinities. The holotype tarsometatarsus of this species (Fig. 1A, B, D) was originally assigned to Procellariidae, as "Puffinus arvernensis" (Shufeldt 1896), and referred to Plotornis by Cheneval (1984). With a length of only $42.6 \mathrm{~mm}$ (Cheneval 1984), the bone is from a bird about half the size of the smallest extant albatross (Fig. 1A, B, D). Its distal end is proportionally narrower than in $P$. delfortrii and other Diomedeidae and, unlike in albatrosses, the articular surface of the trochlea for the fourth toe is not sloping laterally (Fig. 1). In addition to the tarsometatarsus, Cheneval (1984) tentatively referred a coracoid to P. arvernensis, which likewise shows little resemblance to the corresponding bone of albatrosses and was considered to be from a pathological individual. Apart from its morphological dissimilarity, it is highly unlikely that " $P$ ". arvernensis represents an albatross, because the fossils were found in lacustrine sediments that were deposited $>250 \mathrm{~km}$ away from any seashore.

The fragmentary holotype material of "Diomedea" rumana Grigorescu and Kessler, 1988 from the middle Miocene (MN 8, about 12 mya) of Romania, the proximal and distal ends of an ulna (Grigorescu and Kessler 1988), distinctly differs from Diomedeidae and other Procellariiformes in the much larger olecranon and the shape of the tuberculum carpale, and is also unlikely to be from an albatross or even procellariiform bird.

Apart from $P$. delfortrii, the only unambiguous European diomedeid species is thus Phoebastria anglica from the late Pliocene of England, which is represented by a tarsometatarsus and several referred bones (Olson and Rasmussen 2001, Dyke et al.

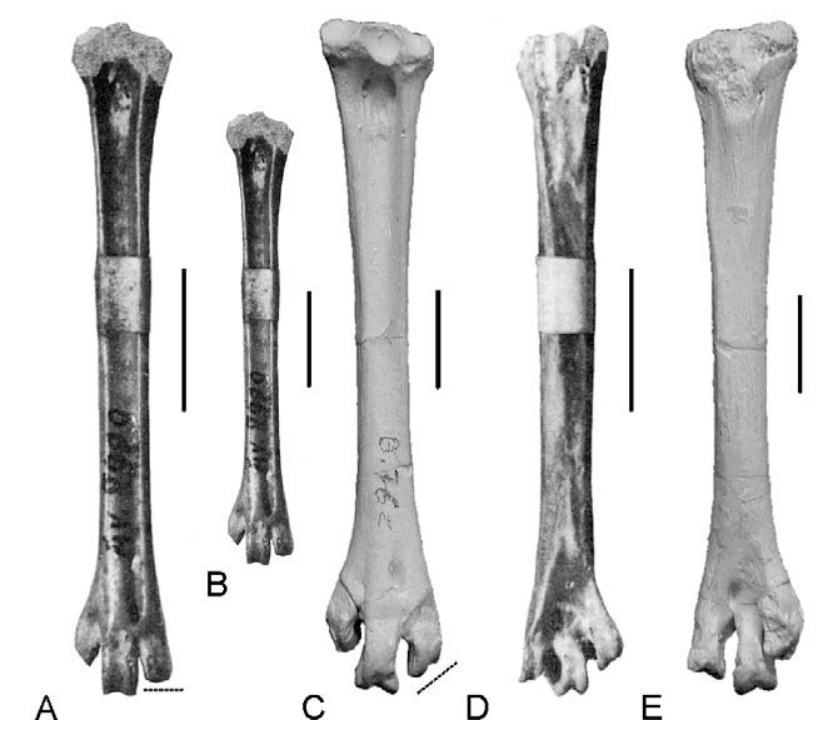

FIG. 1. Left tarsometatarsi of two fossils from the early Miocene of France that were referred to Diomedeidae. (A, B, D) "Plotornis" arvernensis (holotype; from Cheneval 1984) in (A, B) dorsal and (D) plantar view. (C, E) Plotornis delfortrii (cast of holotype in the collection of Université Claude Bernard, Lyon) in (C) dorsal and (E) plantar view. Note the different orientation of the distal end of trochlea metatarsi IV as indicated by the dotted lines in $\mathrm{A}$ and $\mathrm{C}$. In B and C the actual size of the bones are compared. Scale bars $=10 \mathrm{~mm}$.

2007). Soldaat et al. (2009) further mentioned undescribed diomedeid remains from the late Neogene (presumably Pliocene) of the Netherlands.

Even on a global scale, the Paleogene fossil record of albatrosses is very scanty (Mayr 2009b). Murunkus subitus Panteleyev and Nessov, 1987, an alleged diomedeid species from the middle Eocene of Uzbekistan (Panteleyev and Nessov 1987), is known from a single carpometacarpus. Although this specimen closely resembles the carpometacarpus of albatrosses, it is from a very small species, about one-third the size of the smallest extant species, and its affinities need to be established with further material (the assumption that it belongs to the extinct procellariiform Diomedeoididae [Mayr 2009b:77] can, however, not be upheld; De Pietri et al. 2010). Tambussi and Tonni (1988) reported an incomplete tarsometatarsus from the late Eocene of the La Meseta Formation of Seymour Island in Antarctica. The specimen has not been figured, but the authors noted features in which it is distinguished from extant Diomedeidae and resembles Plotornis. These differences evidently refer to "Plotornis" arvernensis, and because that species is unlikely to be an albatross (see above), a restudy of the Seymour Island fossil is desirable. Manu antiquus from the late Oligocene (Duntroonian) of New Zealand (Marples 1946) is based on an incomplete furcula and has been compared with Diomedeidae in the original description. The morphology of the bone is, however, very different from that of extant diomedeids and does not support identification of the species as an albatross (Olson 1985b, Mayr 2009b). As suggested by Mayr (2009b) and Mayr and Rubilar-Rogers (2010), the species may instead belong to the extinct taxon Pelagornithidae (bony-toothed birds). Finally, 
Olson (1985b) mentioned an undescribed, Plotornis-like humerus fragment from the late Oligocene Chandler Bridge Formation in South Carolina.

Here, we describe unambiguous Paleogene records of Diomedeidae from the early Oligocene (Rupelian) of Belgium. The fossils were found in the Boom Formation, whose sediments were deposited in a shallow open sea in the southwestern part of the North Sea Basin (Vandenberghe et al. 2004). Despite the fact that these specimens constitute the most substantial Paleogene fossil record of Diomedeidae found so far, they remained unstudied since their discovery $>100$ years ago.

\section{Material AND Methods}

Osteological terminology follows Baumel and Witmer (1993). For convenience, the term "albatrosses" is used for all crown group Diomedeidae. Institutional abbreviation: IRSNB, Institut royal des Sciences naturelles de Belgique, Belgium.

Comparisons were made with skeletons of the following extant species of Diomedeidae (all in the collection of Forschungsinstitut Senckenberg): Thalassarche cauta, Th. chlororhynchos, Th. melanophris, Diomedea antipodensis, D. epomophora, D. exulans, and Phoebetria fusca. For the humerus, ulna, and carpometacarpus of Phoebastria species, the figures in Olson and Rasmussen (2001) were consulted.

\section{Systematic Paleontology}

\section{Procellariiformes Fürbringer, 1888 \\ Diomedeidae Gray, 1840 Tydea, gen. nov.}

Type species.-Tydea septentrionalis, sp. nov.

Differential diagnosis.-Differs from Plotornis and crown group Diomedeidae in the smaller and more proximally directed processus supracondylaris dorsalis of the humerus (compare Fig. $2 \mathrm{~K}, \mathrm{O}$ ); further differs from crown group Diomedeidae in that crista bicipitalis without marked cranial bulge (compare Fig. 2A, F), impressio ligamenti acrocoracohumeralis of coracoid more marked (Fig. 3H, J), and facies articularis humeralis of scapula proportionally larger and tuberculum coracoideum more prominent (Fig. 3L, M).

Etymology.-From Tydeus, in Greek mythology the father of Diomedes, from which the genus name Diomedea is derived.

\section{Tydea septentrionalis, sp. nov.}

Holotype.-IRSNB Av 94a-m (Figs. 2 and 3; proximal and distal ends of right humerus, fragmentary distal left humerus in two pieces, fragmentary distal end of right ulna, fragmentary distal end of right carpometacarpus, distalmost tip of left carpometacarpus, incomplete right phalanx proximalis digiti majoris, extremitas cranialis and distal section of blade of left scapula, fragmentary right coracoid, tip of processus acrocoracoideus of left coracoid, fragment of left scapus claviculae); all bones are from the same individual; they were found on 10 December 1903 by Georges Hasse.

Type locality and horizon.-Terhagen near Antwerp; Boom Formation, early Oligocene (Rupelian).
Diagnosis.-As for genus; Tydea septentrionalis, sp. nov. was about the size of the extant Thalassarche melanophris.

Measurements (in millimeters).--Humerus, maximum width of proximal end (IRSNB Av 94a), 36.0; maximum width of distal end (IRSNB Av 94b) as preserved, 22.8. Coracoid (IRSNB Av 94k), maximum length as preserved, 40.0. Scapula (IRSNB Av 94i), width of extremitas cranialis, 13.7. Phalanx proximalis digiti majoris (IRSNB Av 94h), maximum length, 45.9. Carpometacarpus (IRSNB Av 94g), maximum craniocaudal width of distal end, 12.7; estimated total length (IRSNB Av 94g + IRSNB Av 95), 95.

Referred specimen.-IRSNB Av 95 (Fig. 3S, T; proximal left carpometacarpus); collection Bernays-de Gottal; from Rumst near Antwerp, early Oligocene (Rupelian).

Etymology.-From septem (Lat.), seven, and triones (Lat.), plow oxen, in reference to the seven stars of the constellation Ursa Major (Great Bear); the term "septentrionalis" refers to northern latitudes.

Comments.-The holotype of Tydea septentrionalis consists of wing and pectoral girdle bones only. However, the material catalogued under IRSNB Av 94 also includes four pedal phalanges, presumably from the fourth toe. Although these match the wing bones in size, they exhibit a morphology very different from the much more elongated and narrower pedal phalanges of albatrosses. Given the great similarity in the morphology of the wing bones, we consider it unlikely that early Oligocene Diomedeidae had a completely different toe morphology than their extant relatives and other procellariiform birds. Because other avian specimens from the Boom Formation in the collection of IRSNB also constitute a mix of different species, we assume that the pedal phalanges are not from $T$. septentrionalis.

Description and comparisons.-In addition to an incomplete right coracoid, which lacks most of the omal and sternal extremities (Fig. 3B-D), the material also includes the tip of the processus acrocoracoideus of the left coracoid (Fig. 3F-H). This latter specimen is similar to the processus acrocoracoideus of Thalassarche spp. in its shape but exhibits a more marked impressio ligamenti acrocoracohumeralis than all extant species of Diomedeidae (Fig. $3 \mathrm{H}$ ), and the facies articularis clavicularis does not form a lip overhanging the sulcus supracoracoideus (this lip is particularly pronounced in Diomedea spp.). On the right coracoid, the foramen nervi supracoracoidei is still filled with sediment but has the same size and position as in modern albatrosses. The overall proportions of the bone closely match those of extant diomedeids. As in modern albatrosses and in contrast to other procellariiform birds, the medial portion of the extremitas sternalis is dorsoventrally wide, and the facies interna of the crista articularis sternalis appears to have been very prominent. Whether the impressio musculi sternocoracoidei on the dorsal surface of the extremitas sternalis bears pneumatic foramina as in crown group diomedeids (Fig. 3A) cannot be discerned owing to the fragmentary and poor preservation of the specimen.

The scapula differs from that of crown group Diomedeidae in that the facies articularis humeralis is proportionally larger, more craniocaudally elongated, and less cranially directed (Fig. 3L, M). The tuberculum coracoideum is somewhat more prominent than in extant albatrosses. The extremitas cranialis as a whole is less ventrally expanded than in the species of crown group Diomedeidae, in which it has a subtriangular shape with a straight cranial 

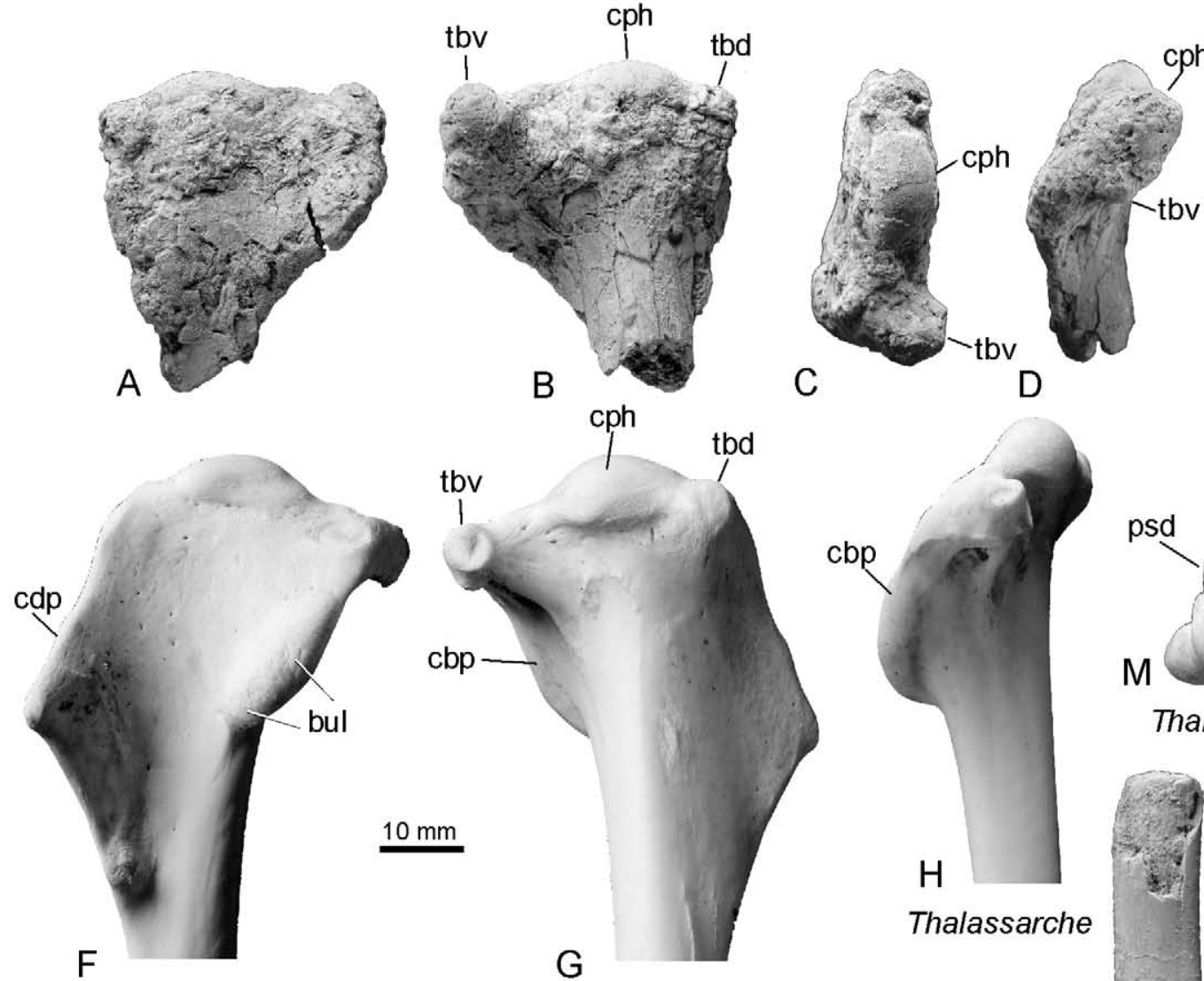

Thalassarche

G Thalassarche
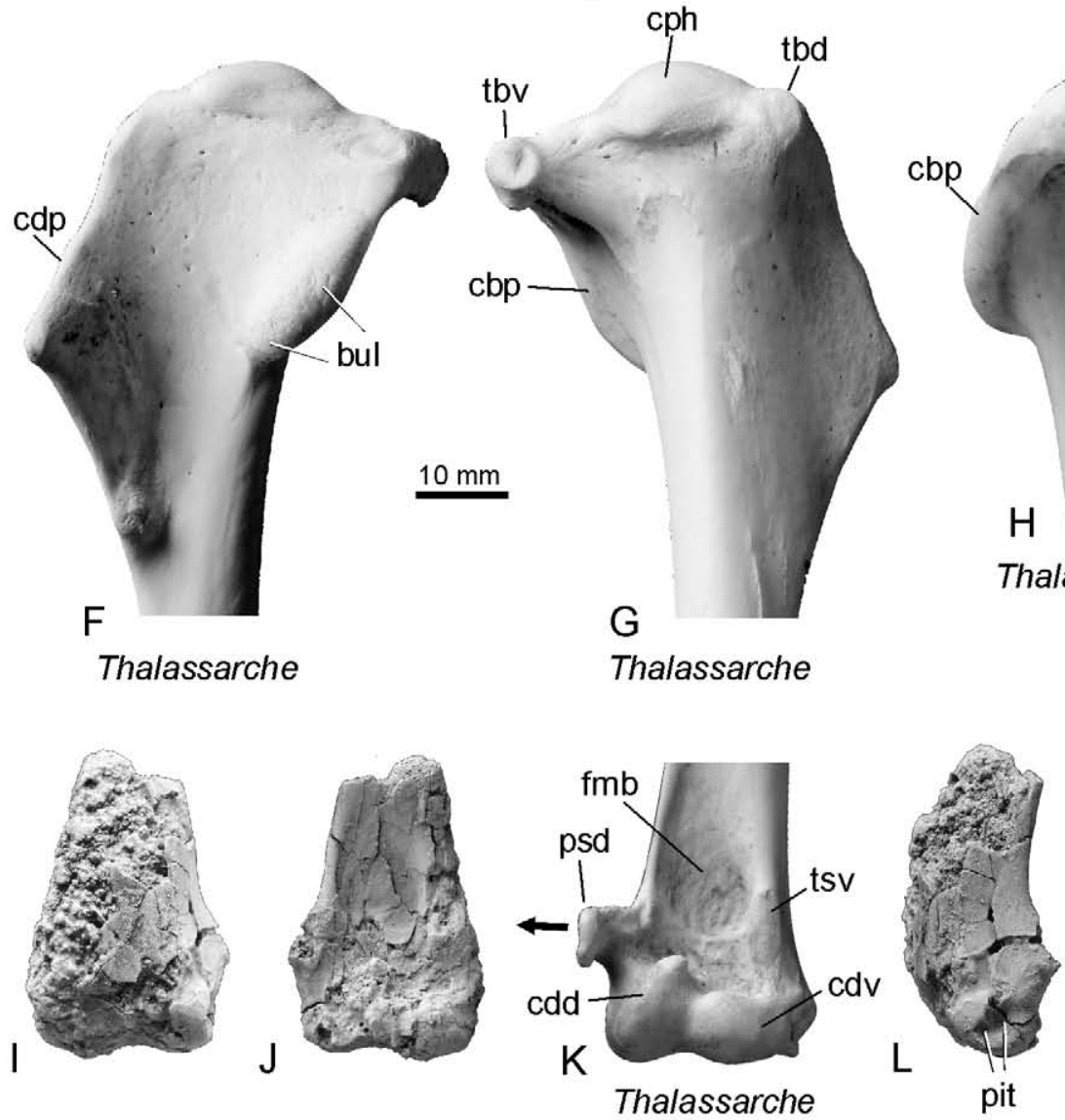

D

$\mathrm{H}$

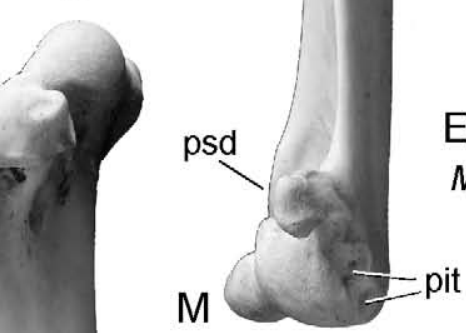

Thalassarche

P

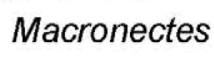

Thalassarche
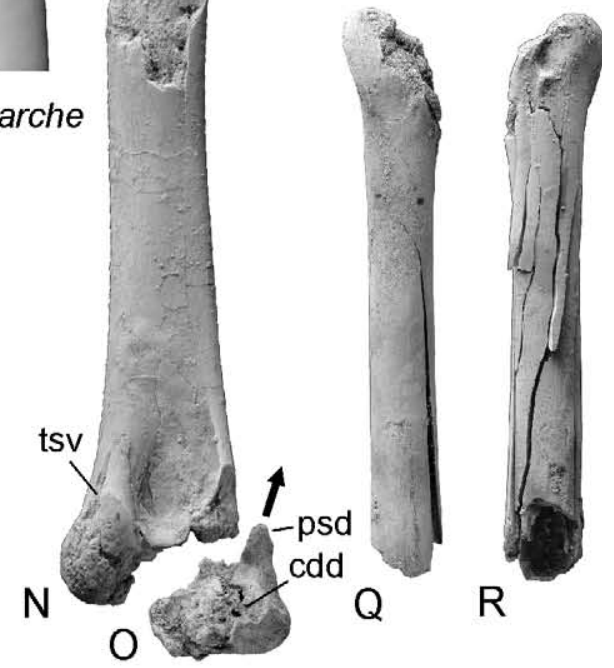

FIG. 2. Humerus and ulna of Tydea septentrionalis, gen. et sp. nov., from the early Oligocene of Belgium in comparison with extant Macronectes giganteus (Procellariidae; E) and Thalassarche melanophris (Diomedeidae; F-H, K, M). (A-D) Proximal end of right humerus (holotype, IRSNB Av 94a) in (A) cranial, (B) caudal, (C) proximal, and (D) ventral view. (E) Proximal end of right humerus of M. giganteus in caudal view. (F, G) Proximal end of right humerus of Th. melanophris in (F) cranial, $(\mathrm{G})$ caudal, and $(\mathrm{H})$ ventral view. $(\mathrm{I}, \mathrm{J}, \mathrm{L})$ Distal end of right humerus (holotype, IRSNB Av 94b) in (I) caudal, (J) cranial, and (L) dorsal view. (K) Distal end of right humerus of Th. melanophris in cranial view. (M) Distal end of left humerus of Th. melanophris in dorsal view. (N) Distal end of left humerus (holotype, IRSNB Av 94c) in cranial view. (O, P) Distodorsal portion of left humerus (holotype, IRSNB Av 94d) in (O) cranial and (P) dorsal view. (Q, R) Distal end of right ulna (IRSNB Av 94e) in (Q) ventral and $(\mathrm{R})$ dorsal view. The arrows in $\mathrm{K}$ and $\mathrm{O}$ indicate the direction of the processus supracondylaris dorsalis. All fossil specimens coated with ammonium chloride. Abbreviations: bul = cranial bulge of crista bicipitalis, $c b p=$ crista bicipitalis, $c d d=$ condylus dorsalis, $c d f=c r u s$ dorsale fossae, $\mathrm{cdp}=$ crista deltopectoralis, $\mathrm{cdv}=$ condylus ventralis, $\mathrm{cph}=$ caput humeri, $\mathrm{fmb}=$ fossa musculi brachialis, $\mathrm{fpt}=\mathrm{fossa}$ pneumotricipitalis, pit = pits on epicondylus dorsalis, $\mathrm{psd}=$ processus supracondylaris dorsalis, $\mathrm{tbd}=$ tuberculum dorsale, tbv = tuberculum ventrale, and tsv = tuberculum supracondylare ventrale. 


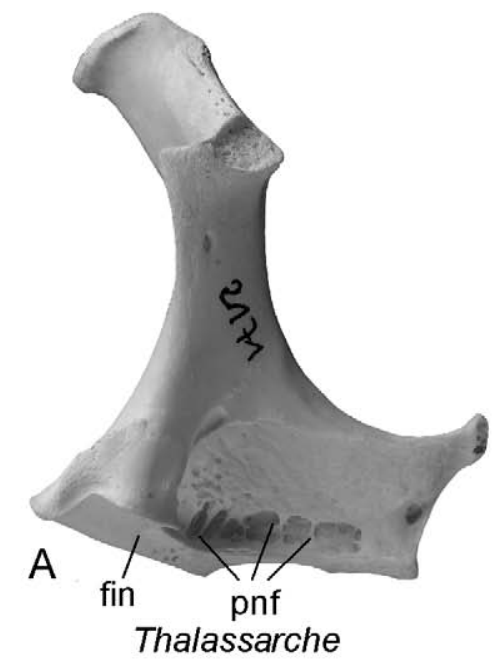

B

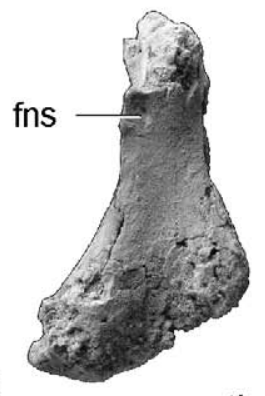

$\mathrm{F}$
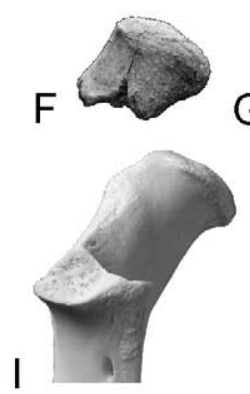

G
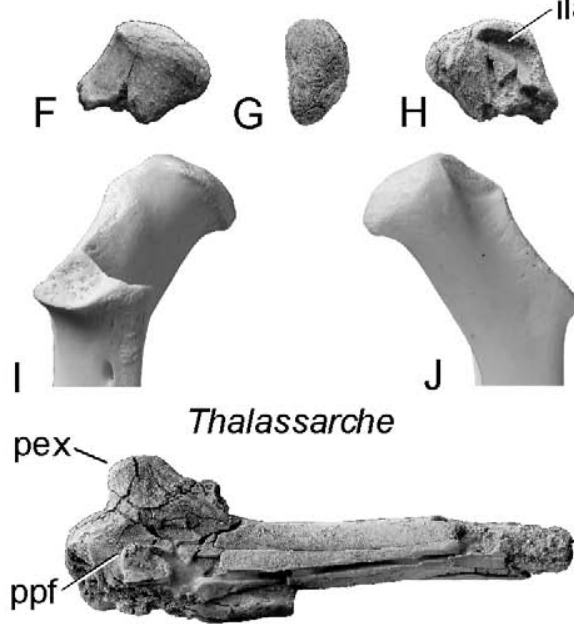

$\mathrm{S}$

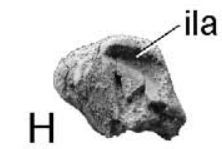

ila

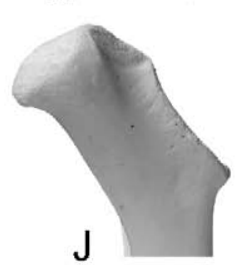

$10 \mathrm{~mm}$
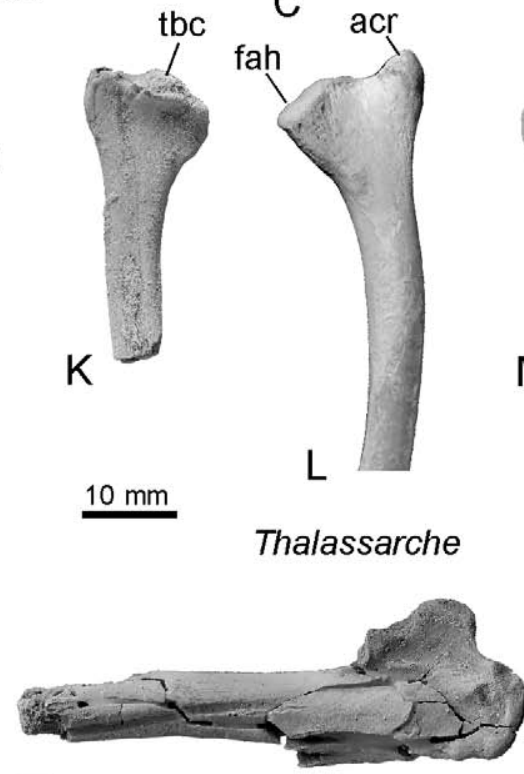

$\mathrm{T}$

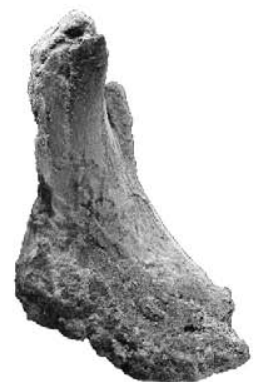

C

fah

acr

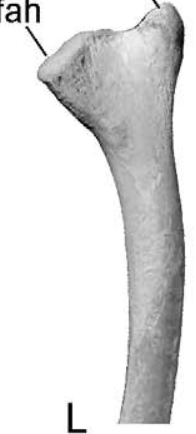

Thalassarche
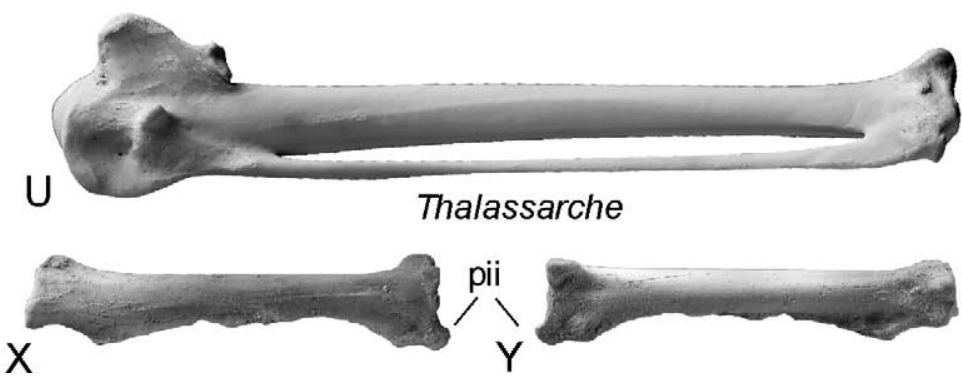

D

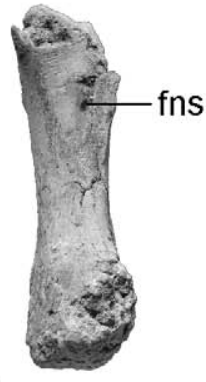

E

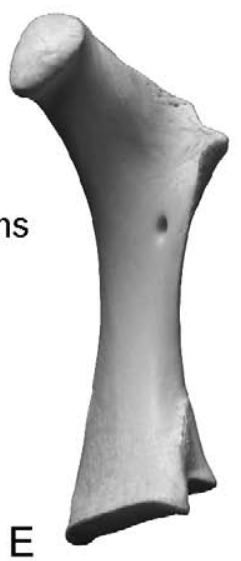

Thalassarche

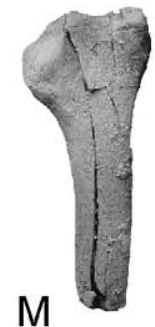

$\mathrm{O}$
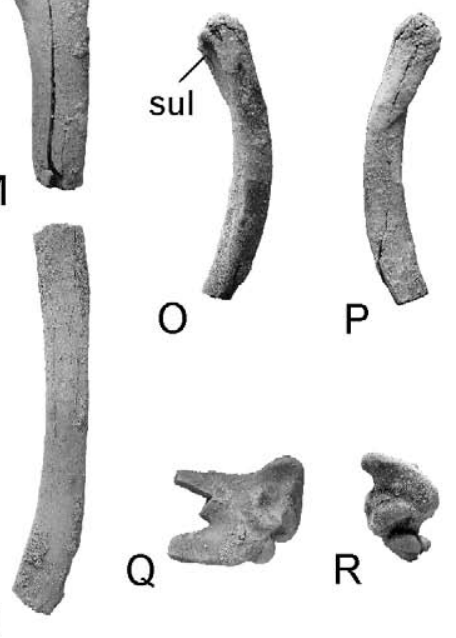

$\mathrm{N}$

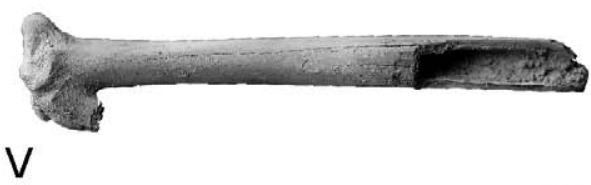

W

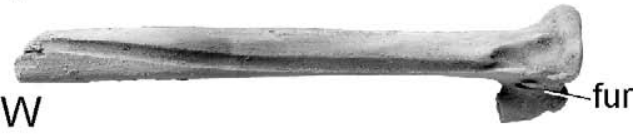

FIG. 3. Wing and pectoral girdle bones of Tydea septentrionalis, gen. et sp. nov., from the early Oligocene of Belgium in comparison to extant Thalassarche melanophris (Diomedeidae). (A, E) Right coracoid of Th. melanophris in (A) dorsal and (E) medial view. (B-D) Fragmentary right coracoid (holotype, IRSNB Av 94k) in (B) dorsal, (C) ventral, and (D) medial view. (F-H) Processus acrocoracoideus of left coracoid (holotype, IRSNB Av 94l) in (F) dorsal, (G) omal, and (H) ventral view. (I, J) Processus acrocoracoideus of left coracoid of Th. melanophris in (I) dorsal and (J) ventral view. (K, M, N) Left scapula (holotype, IRSNB Av 94i+j) in (K) medial and $(\mathrm{M}, \mathrm{N})$ lateral view. (L) Left scapula of Th. melanophris in lateral view. (O, P) Fragment of omal section of left scapus claviculae (holotype, IRSNB Av 94m) in (O) cranial and (P) caudal view. (Q, R) Distal tip of left carpometacarpus (holotype, IRSNB Av 94g) in (Q) ventral and (R) distal view. (S, T) Proximal left carpometacarpus (IRSNB Av 95) in (S) ventral and (T) dorsal view. (U) Left carpometacarpus of Th. melanophris in ventral view. (V, W) Distal section of right carpometacarpus (holotype, IRSNB Av 94f) in (V) ventral and (W) dorsal view. (X, Y) Right phalanx proximalis digiti majoris (holotype, IRSNB Av 94h) in (X) dorsal and (Y) ventral view. All fossil specimens coated with ammonium chloride. Abbreviations: $\mathrm{acr}=$ acromion, $\mathrm{fah}=$ facies articularis humeralis, $\mathrm{fin}=$ facies interna of crista articularis sternalis, fns = foramen nervi supracoracoidei, fur $=$ tendinal furrows of musculi interosseus dorsalis et ventralis, ila = impressio ligamenti acrocoracohumeralis, pex = processus extensorius, pii $=$ processus internus indicis, $\mathrm{pnf}=$ pneumatic foramina, $\mathrm{ppf}=$ processus pisiformis, sul = medial sulcus on scapus claviculae, and tbc = tuberculum coracoideum . 
margin in Thalassarche and Phoebetria and a much more prominent acromion in Diomedea.

Only a small portion of the left scapus claviculae of the furcula is preserved, which stems from the proximal section, just sternal of the extremitas omalis (Fig. 3O, P). The bone fragment agrees well with the corresponding section of the furcula of extant diomedeids. Its sternal half has a convex cranial and flat caudal surface, and the omal portion bears a shallow notch on its craniolateral surface. Unlike in modern diomedeids, however, there is a sulcus on the medial surface of the omal portion, at the base of the extremitas omalis (Fig. 3O).

Because of the action of pyrite decay, the proximal end of the humerus is badly preserved, and there is still very hard matrix attached to parts of the bone. The characteristic derived features of the albatross humerus are, nevertheless, clearly visible, and apart from the characters noted below, the preserved morphology closely resembles the proximal humerus of extant diomedeids. The proximal margin of the bone is straight, and the caput humeri is small and only weakly proximally protruding. The tuberculum ventrale is strongly developed and the incisura capitis very wide as in modern albatrosses. The sulcus transversus appears to have been very short and shallow as in the extant species, but its exact extent is not visible because of overlying matrix. As in the recent species of Diomedeidae and unlike in other procellariiform birds, the crus dorsale fossae is reduced and the fossa pneumotricipitalis shallow (Fig. 2B). A pneumatic foramen within the latter fossa is not visible, but the corresponding area is too poorly preserved for close examination. In crown group diomedeids, the crista bicipitalis forms a very marked cranial bulge and has a bloated appearance (Fig. 2F). Although the corresponding area of the humerus is damaged in the fossil, a large cranial protrusion almost certainly was absent. The crista bicipitalis itself is less proximodistally stretched than in the species of crown group Diomedeidae and, contrary to the latter, it is cranially raised in its proximal section. In ventral view, the proximal portion of the crista bicipitalis, just distal of the tuberculum ventrale, is thus craniocaudally wider than in crown group diomedeids (Fig. 2D). The crista deltopectoralis is broken; the caudal surface of the humerus adjacent to it is slightly concave, whereas it is flat in crown group diomedeids. In its distal section, the dorsal margin of the shaft is craniocaudally slanted as in extant albatrosses; the narrow ventral margin forms a ridge. The fossa musculi brachialis is very wide and shallow as in the species of extant Diomedeidae. The condylus dorsalis is too damaged for meaningful comparisons. The condylus ventralis matches that of modern diomedeids, and as in the latter, the ventral portion of this condyle slants craniocaudally. The tuberculum supracondylare ventrale is elongated as in modern albatrosses and has a slightly convex cranial surface (on the right humerus the proximal portion of this tubercle is missing). The processus supracondylaris dorsalis of the right humerus is broken, but the process is preserved on the isolated distodorsal portion of the left humerus (Fig. 2O, P). Although the humerus shaft is not preserved in this fragment, the processus supracondylaris dorsalis is complete and much smaller and more proximally directed than in other Diomedeidae, including Plotornis, in which it is a large dorsal projection perpendicular to the long axis of the humerus (Fig. 2K). The two ligamental pits on the dorsal surface of the epicondylus dorsalis are further situated more closely together than in crown group diomedeids, in which they are well separated (Fig. 2L, M).

The poorly preserved ulna (Fig. 2Q, R) does not allow for extensive comparisons, but the morphologies of the condylus dorsalis, depressio radialis, and incisura tendinosa do not differ from the species of extant Diomedeidae (e.g., Thalassarche melanophris).

Likewise, the carpometacarpus closely resembles that of extant diomedeids (Fig. 3 ) and, apart from being about $3 \times$ larger, is also similar to that of the middle Eocene Murunkus subitus. As in extant albatrosses and $M$. subitus, the tip of the processus extensorius is wide and broadly rounded, whereas it is more pointed in other Procellariiformes. The processus pisiformis forms a trough for the tendon of musculus flexor digitorum profundus. On the dorsal surface of the proximal end of the bone, the fossa supratrochlearis is marked as in Phoebetria fusca and Diomedea spp., whereas it is shallow in Thalassarche spp. The sulcus tendinosus slopes caudally toward the distal end of the bone; the fossa at its distal end is proportionally somewhat shorter than in modern albatrosses (in the fossil it begins at the end of the spatium intermetacarpale, whereas it starts well before in crown group diomedeids). As in the species of crown group Diomedeidae, there are two short but well-marked sulci for the tendons of musculi interosseus dorsalis et ventralis on the dorsal surface of the symphysis metacarpi distalis (Fig. 3W). Also as in extant albatrosses and M. subitus, the facies articularis digitalis minor does not reach as far distally as facies articularis digitalis major.

The preserved portion of the phalanx proximalis digiti majoris (Fig. 3X, Y) does not differ from that of extant diomedeids; as in the latter, there is a small processus internus indicis.

\section{Discussion}

Assignment of Tydea septentrionalis, gen. et sp. nov., to Diomedeidae is straightforward and, apart from the large size of the remains, supported by the characteristic derived morphology of the humerus, which, unlike in other Procellariiformes, exhibits (1) a strongly reduced crus dorsale fossae, (2) a shallow fossa pneumotricipitalis, and (3) a very long and narrow tuberculum supracondylare ventrale. Further derived morphologies shared by $T$. septentrionalis and crown group diomedeids are (4) the wide and broadly rounded processus extensorius of the carpometacarpus and (5) the extremitas sternalis of the coracoid, whose medial section is very wide dorsoventrally (Fig. 3D, E). The species is distinguished from Pelagornithidae, the only avian taxon with which a confusion would be possible, by several features, such as the thicker bone walls, the smaller processus acrocoracoideus of the coracoid, the morphology of the proximal humerus, whose caput, for example, does not form a cranial overhang, the less concave lateral surface of the extremitas cranialis of the scapula, and the less proximodistally elongated processus extensorius and symphysis metacarpalis distalis of the carpometacarpus (e.g., Bourdon et al. 2010, Mayr and Smith 2010, Mayr and Zvonok 2011).

The furcula of Tydea septentrionalis is very unlike that of Manu antiquus from the late Oligocene of New Zealand, in which the omal section of the scapus claviculae is much wider, thus providing further evidence against diomedeid affinities of this latter species (see above). 
Although T. septentrionalis closely resembles the species of extant Diomedeidae in its overall morphology, it is shown to be outside crown group Diomedeidae by several plesiomorphic features, such as (1) the shorter processus supracondylaris dorsalis (as detailed by Mayr 2009a, a short process is plesiomorphic for Procellariiformes), (2) the absence of a marked cranial bulge on the crista bicipitalis (this feature is an autapomorphy of crown group diomedeids and does not occur in other Procellariiformes and most other birds), (3) the marked impressio ligamenti acrocoracohumeralis of the coracoid (the impression is marked in Procellariidae and most other birds), and (4) the larger facies articularis humeralis of the scapula (the condition in Tydea resembles that in non-diomedeid Procellariiformes).

The Rupelian deposits of the Boom Formation in Terhagen have an age of 30-31 Ma (Abels et al. 2007), and Tydea septentrionalis is thus $\geq 8$ Ma older than the early Miocene Plotornis delfortrii, which comes from the Neogene stratigraphic unit MN 2-3 (Cheneval 1996) and has an age of 22 million years. Nunn et al. (1996) estimated that the earliest divergences within the two major clades of crown group Diomedeidae occurred about 23 mya (Diomedea-Phoebastria) and 28 mya (Phoebetria-Thalassarche), and our study provides a calibration point outside the crown group for future divergence estimates based on molecular data.

Tydea septentrionalis is the first Paleogene record of Diomedeidae from the North Sea Basin and documents a long evolutionary history of albatrosses on the Northern Hemisphere. Previous Paleogene records of putative Diomedeidae (i.e., the early Eocene Murunkus subitus and the unnamed late Eocene record from Antarctica) represent species significantly smaller than extant albatrosses. As shown by T. septentrionalis, however, albatrosses had already reached a large size in the early Oligocene.

The close similarity of the wing bones, especially the shape of the proximal humerus, whose small caput restricted rotatory movements, indicates that T. septentrionalis was already well adapted to soaring over long distances. Notably, however, the processus supracondylaris dorsalis on the distal humerus is distinctly shorter and more proximally directed in T. septentrionalis than in Plotornis and extant Diomedeidae (Fig. 2K, O). This process serves as attachment site for the tendon of musculus extensor carpi radialis and ligaments connected with the ligamentum propatagiale, and its enlargement in procellariiform birds is often correlated with the presence of a large, strut-like sesamoid bone, which stabilizes the propatagium (Brooks 1937, Mayr 2009a). The distinct differences in the development of this process in T. septentrionalis and crown group Diomedeidae are likely to correspond with differences in flight technique or aerodynamic characteristics of the wing, and the fossil species may not yet have been adapted to dynamic soaring to the same degree as crown group Diomedeidae (e.g., Pennycuick 1982). A detailed analysis of the functional morphology of the supracondylar process in extant Procellariiformes is, however, needed before conclusions can be drawn on its significance in the fossil.

Early Oligocene terrestrial avifaunas of Europe include many groups that do not occur on this continent today, such as hummingbirds and todies (Mayr 2009b), and our study adds a marine taxon to this list. Albatrosses obtain their food, mainly squid and fish, from the sea surface, and most extant species occur in areas with productive marine upwellings, such as the Benguela Current along southwest Africa and the Humboldt Current at the South
American west coast. Distribution of these highly pelagic birds in the high latitudes of the Southern Hemisphere is also favored by the persistence of strong winds, whereas most of the much calmer equatorial regions do not offer suitable habitats for albatrosses (Carboneras 1992). Early Oligocene global oceanic and atmospheric circulation systems were, however, very different from those of today. Although a proto-Humboldt current may have already existed in the late Eocene (Marty et al. 1988), strong coastal upwelling commenced in the early Miocene (Ibaraki 1997), and onset of high productivity of the Benguela Current was not before the late Miocene (Diester-Haass et al. 2002). Global atmospheric circulation was also subjected to changes through time, and today's wind distribution is, among other factors, a result of the marked pole-to-equator temperature gradients, which emerged during the Cenozoic (Rea and Janecek 1982).

Occurrence of albatrosses in the Oligocene of the North Sea basin probably reflects such historical geophysical differences, but albatrosses persisted in the North Atlantic until the late Pliocene (England) or even Pleistocene (Bermuda), and the reasons that led to their extinction are poorly understood. Olson and Hearty (2003) hypothesized that a mid-Pleistocene interglacial sea-level rise led to the extirpation of a Phoebastria albatrus breeding colony on Bermuda, but these authors also noted that other North Atlantic albatross species seem to have vanished before. North Atlantic seabird communities in general were much more diversified in the Pliocene than they are today (Olson and Rasmussen 2001, Olson and Hearty 2003, Smith 2011), and disappearance of albatrosses from the North Atlantic was only one chapter in the profound turnovers in seabird communities during the Pliocene, a period that, for example, witnessed the global extinction of the large pelagornithids, which were also large marine soaring birds (Mayr and Rubilar-Rogers 2010). Both tectonic processes (e.g., changes in oceanic circulation systems due to closure of the Panamanian Isthmus and disappearance of breeding grounds because of sea-level rises) and ecological interactions (e.g., competition for breeding space with gregarious pinnipeds) have been considered important factors in the evolution of seabird communities (Warheit 1992, 2002), but a full understanding is still hampered by our incomplete knowledge of the exact temporal and geographic distribution of many taxa in question (Olson and Hearty 2003). It is notable that there are few, if any, records of large marine Laridae and Stercorariidae before the Pliocene (Olson 1985b, De Pietri et al. 2011). Whether there is any causal relation between the late diversification of these birds and the extinction of other seabird taxa cannot, however, be established with the data at hand.

\section{ACKNOWLEDGMENTS}

We thank A. Folie (IRSNB) for organizing the loan of the fossil birds to G.M., V. De Pietri and Y. Zahn (Naturhistorisches Museum der Burgergemeinde Bern) for assisting in literature research, U. Göhlich (Naturhistorisches Museum Wien) for photos of $P$. delfortrii casts, and S. Tränkner (Forschungsinstitut Senckenberg) for taking the photographs of the Belgian fossils and the extant specimens. Comments by $\mathrm{T}$. Worthy and an anonymous reviewer improved the manuscript. This study is a contribution to project MO/36/020 supported by the Federal Science Policy Office of Belgium. 


\section{Literature Cited}

Abels, H. A., S. Van Simaeys, F. J. Hilgen, E. De Man, and N. VANDENBERGHE. 2007. Obliquity-dominated glacio-eustatic sea level change in the early Oligocene: Evidence from the shallow marine siliciclastic Rupelian stratotype (Boom Formation, Belgium). Terra Nova 19:65-73.

Baumel, J. J., And L. M. Witmer. 1993. Osteologia. Pages 45-132 in Handbook of Avian Anatomy: Nomina Anatomica Avium (J. J. Baumel, A. S. King, J. E. Breazile, H. E. Evans, and J. C. Vanden Berge, Eds.). Publications of the Nuttall Ornithological Club, no. 23.

Bourdon, E., M. Amaghzaz, and B. Bouya. 2010. Pseudotoothed birds (Aves, Odontopterygiformes) from the early Tertiary of Morocco. American Museum Novitates 3704:1-71.

Brooke, M. 2004. Albatrosses and Petrels across the World. Oxford University Press, Oxford, United Kingdom.

Brooks, A. 1937. The patagial fan in the Tubinares. Condor 39:82-83.

Carboneras, C. 1992. Family Diomedeidae (Albatrosses). Pages 198-215 in Handbook of the Birds of the World, vol. 1 (J. del Hoyo, A. Elliott, and J. Sargatal, Eds.). Lynx Edicions, Barcelona, Spain.

Cheneval, J. 1984. Les oiseaux aquatiques (Gaviiformes à Ansériformes) du gisement aquitanien de Saint-Gérand-le-Puy (Allier, France): Révision systématique. Palaeovertebrata 14:33-115.

Cheneval, J. 1996. Miocene localities of France. Acta Universitatis Carolinae, Geologica 39:599-611.

Davis, P. C. 2003. The oldest record of the genus Diomedea, Diomedea tanakai sp. nov. (Procellariiformes: Diomedeidae): An albatross from the Miocene of Japan. Bulletin of the National Science Museum, Tokyo, Series C 29:39-48.

De Pietri, V. L., J.-P. Berger, C. Pirkenseer, L. Scherler, and G. MAYR. 2010. New skeleton from the early Oligocene of Germany indicates a stem-group position of diomedeoidid birds. Acta Palaeontologica Polonica 55:23-34.

De Pietri, V. L., L. Costeur, M. Güntert, and G. Mayr. 2011. A revision of the Lari (Aves: Charadriiformes) from the early Miocene of Saint-Gérand-le-Puy (Allier, France). Journal of Vertebrate Paleontology 31:812-828.

Diester-HaAss, L., P. A. Meyers, And L. Vidal. 2002. The late Miocene onset of high productivity in the Benguela Current upwelling system as part of a global pattern. Marine Geology 180:87-103.

Dyke, G. J., R. L. Nudds, And C. A. Walker. 2007. The Pliocene Phoebastria ('Diomedea') anglica: Lydekker's English fossil albatross. Ibis 149:626-631.

Grigorescu, D., And E. Kessler. 1988. New contributions to the knowledge of the Sarmatian birds from South Dobrogea in the frame of the eastern Paratethyan avifauna. Revue Roumaine de Géologie, Géophysique et Géographie (Géologie) 32:91-97.

IbARAKI, M. 1997. Closing of the Central American Seaway and Neogene coastal upwelling along the Pacific coast of South America. Tectonophysics 281:99-104.

MARPLES, B. J. 1946. Notes on some neognathous bird bones from the early Tertiary of New Zealand. Transactions of the Royal Society of New Zealand 76:132-134.

Marty, R., R. Dunbar, J. B. Martin, And P. Baker. 1988. Late Eocene diatomite from the Peruvian coastal desert, coastal upwelling in the eastern Pacific, and Pacific circulation before the terminal Eocene event. Geology 16:818-822.
MAYR, G. 2009a. Notes on the osteology and phylogenetic affinities of the Oligocene Diomedeoididae (Aves, Procellariiformes). Fossil Record 12:133-140.

MAyr, G. 2009b. Paleogene Fossil Birds. Springer, Heidelberg.

MAYr, G., AND D. Rubilar-Rogers. 2010. Osteology of a new giant bony-toothed bird from the Miocene of Chile, with a revision of the taxonomy of Neogene Pelagornithidae. Journal of Vertebrate Paleontology 30:1313-1330.

Mayr, G., AND T. Smith. 2010. Bony-toothed birds (Aves: Pelagornithidae) from the Middle Eocene of Belgium. Palaeontology 53:365-376.

Mayr, G., And E. Zvonok. 2011. Middle Eocene Pelagornithidae and Gaviiformes (Aves) from the Ukrainian Paratethys. Palaeontology 54:1347-1359.

Milne-Edwards, A. 1874. Observations sur les oiseaux fossiles des Faluns de Saucats et de la mollasse de Léognan. Bibliothéque de l'École des Hautes Études, Section des Sciences Naturelles 11:3-12.

Nunn, G. B., J. Cooper, P. Jouventin, C. J. R. Robertson, And G. G. Robertson. 1996. Evolutionary relationships among extant albatrosses (Procellariiformes: Diomedeidae) established from complete cytochrome-b gene sequences. Auk 113:784-801.

OLSON, S. L. 1984. Evidence of a large albatross in the Miocene of Argentina (Aves: Diomedeidae). Proceedings of the Biological Society of Washington 97:741-743.

Olson, S. L. 1985a. Early Pliocene Procellariiformes (Aves) from Langebaanweg, South-western Cape Province, South Africa. Annals of the South African Museum 95:123-145.

Olson, S. L. 1985b. The fossil record of birds. Pages 79-238 in Avian Biology, vol. 8. (D. S. Farner, J. R. King, and K. C. Parkes, Eds.). Academic Press, New York.

Olson, S. L., And P. J. Hearty. 2003. Probable extirpation of a breeding colony of Short-tailed Albatross (Phoebastria albatrus) on Bermuda by Pleistocene sea-level rise. Proceedings of the National Academy of Sciences USA 100:12825-12829.

Olson, S. L., And P. C. Rasmussen. 2001. Miocene and Pliocene birds from the Lee Creek Mine, North Carolina. Smithsonian Contributions to Paleobiology 90:233-365.

Panteleyev, A. V., And L. A. Nessov. 1987. A small tubinare (Aves: Procellariiformes) from the Eocene of Middle Asia. [In Russian.] Trudy Zoologicheskogo Instituta 252:95-103.

Pennycuick, C. J. 1982. The flight of petrels and albatrosses (Procellariiformes), observed in South Georgia and its vicinity. Philosophical Transactions of the Royal Society of London, Series B 300:75-106.

ReA, D. K., AND T. R. JANECEK. 1982. Late Cenozoic changes in atmospheric circulation deduced from North Pacific eolian sediments. Marine Geology 49:149-167.

SHufeldt, R. W. 1896. Fossil bones of birds and mammals from Grotto Pietro Tamponi and Grive-St. Alban. Proceedings of the Academy of Natural Sciences of Philadelphia 1896:507-516.

Smith, N. A. 2011. Taxonomic revision and phylogenetic analysis of the flightless Mancallinae (Aves, Pan-Alcidae). ZooKeys 91:1-116.

SoldaAt, E., M. F. Leopold, E. H. Meesters, and C. J. R. RobERTSON. 2009. Albatross mandible at archeological site in Amsterdam, The Netherlands, and WP records of Diomedea albatrosses. Dutch Birding 31:1-16. 
StUCChi, M., AND M. URBinA. 2005. Nuevos restos de Procellariiformes (Aves) de la Formacion Pisco, Peru. Boletin de la Sociedad Geológica del Perú 100:67-77.

Tambussi, C. P., And E. P. Tonni. 1988. Un Diomedeidae (Aves: Procellariiformes) del Eoceno tardío de Antártida. Jornadas Argentinas de Paleontología de Vertebrados 5:34-35.

Vandenberghe, N., S. Van Simaeys, E. Steurbaut, J. W. M. Jagt, AND P. J. FELDER. 2004. Stratigraphic architecture of the Upper Cretaceous and Cenozoic along the southern border of the North Sea Basin in Belgium. Netherlands Journal of Geosciences 83:155-171.

Walsh, S. A., And J. P. Hume. 2001. A new Neogene marine avian assemblage from north-central Chile. Journal of Vertebrate Paleontology 21:484-491.
WARHEIT, K. I. 1992. A review of the fossil seabirds from the Tertiary of the North Pacific: Plate tectonics, paleoceanography, and faunal change. Paleobiology 18:401-424.

WARHEIT, K. I. 2002. The seabird fossil record and the role of paleontology in understanding seabird community structure. Pages 17-55 in Biology of Marine Birds (E. A. Schreiber and J. Burger, Eds.). CRC Marine Biology Series, Boca Raton, Florida.

Wilkinson, H. E. 1969. Description of an Upper Miocene albatross from Beaumaris, Victoria, Australia, and a review of the fossil Diomedeidae. Memoirs of the National Museum of Victoria 29:41-51.

Associate Editor: M. T. Murphy 